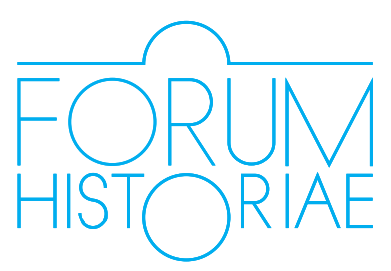

\title{
Sociálna zmena v biografických naratívoch obyvatelov dnešného Slovenska. Od Mníchova po 14. marec 1939
}

\author{
Monika Vrzgulová
}

\begin{abstract}
:
VRZGULOVÁ, Monika: A Social Change in the Biographical Narratives of the Inhabitants of Today's Slovakia - From the Munich Agreement to $14^{\text {th }}$ March 1938.

This paper provides information about the social change that started in autumn 1938 and the way this historical period is reflected in the biographical narratives of witnesses of today's Slovak Republic. The author analysed oral histories from 200 interviews that focused on memories of the period from September 1938 (Munich Agreement) to March 1939 (establishment of the wartime Slovak State). She concentrated on two questions: 1 . Which images, moments and situations represented social change in this historical period for the witness? 2. How do the biographical narratives describe the social change at a local level, in both the public sphere as well as in private within families? The author is interested in the relationship between the communicative and cultural memory (A. Assmann) and the relationship between memory and identity.
\end{abstract}

Keywords: Biographical Narratives, Social Change, Communicative and Cultural Memory, Jews, Persecution

DOI: https://doi.org/10.31577/forhist.2019.13.1.9

$\mathrm{V}$

o svojich výskumoch sa dlhodobo zaoberám problematikou komunikatívnej a kultúrnej pamäti. ${ }^{1}$ Skúmam, akým spôsobom respondentky a respondenti vo svojich biografických naratívoch konštruujú prežitú minulost', ako sa ich spomienky stávajú súčastou verejného diskurzu. ${ }^{2} \mathrm{~V}$ tomto texte sa venujem spomienkam, ktoré reflektujú sociálnu zmenu ${ }^{3}$ v spoločnosti počas druhej ČSR na Slovensku, v období existencie autonómnej Slovenskej krajiny. Procesy v spoločnosti v tomto období pokladám za sociálnu zmenu, ktorú vyvolala medzinárodná

\footnotetext{
* Štúdia vznikla v rámci projektu VEGA 2/0022/17: Vojnový slovenský štát a holokaust v súčasnom verejnom diskurze na Slovensku (Etnologický pohl'ad) a vychádza aj z materiálu, ktorý som skúmala počas štipendijného pobytu ako Guzenberger-Reichman Family Fellow na Jack, Joseph and Morton Mandel Center for Advanced Holocaust Studies, United States Holocaust Memorial Museum v roku 2018.

1 Pri skúmaní tejto problematiky pracujem s terminológiou definovanou v práci ASSMANN, Aleida. Shadows of Trauma, New York : Fordham University Press, 2016.

$2 \mathrm{~V}$ tomto prípade verejný diskurz chápem ako vyjadrenie poznania, myslenia, inštitucionálnej praxe a hodnotení sledovanej historickej doby. Viac FOUCAULT, Michel. The Order of Discourse, In YOUNG, Robert (ed.) Untying the Text, London : Routledge; Boston : Kegan Paul, 1981, s. 48-79.

3 Pojem sociálna zmena znamená dynamiku a diskontinuitu, ktorá sa môže týkat’ demografických procesov, sociálnych štruktúr, kultúrnych vzorcov, spoločností a ich subsystémov, organizácií, inštitúcií alebo skupín. Pozri SUUBRT, Jiří - PFEIFEROVÁ, Štepánka (eds.) Sociální změna. Praha : FHS, 2013, s. 5. Sociálna zmena prináša premenu noriem hodnotového systému v zasiahnutej spoločnosti. Ku sociálnej zmene dochádza pod vplyvom rôznych faktorov, ktoré ovplyvňujú postoje a konanie l'udí, ich kultúru v najširšom zmysle slova, teda aj ich vzt’ahy a komunikáciu. Medzi takéto faktory akcelerujúce zmenu patria: fyzické prostredie, kultúrne vplyvy, politická organizácia, konflikty kvôli zdrojom a hodnotám, vel'kost' a štruktúra populácie, inovácia (vynálezy, objavy, nové technológie) a difúzia (prelínanie prvkov jednej kultúry do inej). Viac: FORM, William - WILTERDINK, Nico. Social Change. In Encyclopaedia Britannica. Dostupné na internete: https://www. britannica.com/topic/social-change.
} 
politická situácia, ale aj vnútropolitické procesy najskôr v politickom systéme. Tie následne akcelerovali zmeny hodnotového systému spoločnosti, ktoré zasahovali do individuálnych životov l'udí. Spomienky týchto l'udí boli v centre mojich výskumov.

Sledované historické obdobie som si pracovne ohraničila podpísaním Mníchovskej dohody (29. september 1938) a vyhlásením samostatného slovenského štátu (14. marec 1939). Vybraté biografické naratívy som podrobila obsahovej analýze. Sústredila som sa v nich na opisy a reprezentácie zmien, ktoré zasiahli do životov respondentov na území dnešnej Slovenskej republiky. Výskumnú vzorku tvoria video- a audiozáznamy rozhovorov pamätníkov a ich prepisy, ktoré sa nachádzajú v oral history archívoch v United States Holocaust Memorial Museum (USHMM), USC Shoah Foundation Visual History Archive (USC SF VHA) a videoarchíve Nadácie Milana Šimečku (NMŠ). Pracovala som aj s nahrávkami z vlastných výskumov. Celý analyzovaný korpus tvorilo 200 rozhovorov, z nich naratívy židovských svedkov holokaustu predstavovali približne $60 \%$. Väčšina analyzovaných rozhovorov bola nakrútená $\mathrm{v}$ polovici 90 . rokov 20. storočia $\mathrm{v}$ slovenskom jazyku v rámci medzinárodných výskumných projektov realizovaných vyššie zmienenými inštitúciami. Moje vlastné výskumy som realizovala predovšetkým v rozmedzí rokov 2006 - 2015. Tieto biografické naratívy predstavujú pre mňa komunikatívnu pamät' - subjektívne konštrukcie životných príbehov pamätníkov sledovanej doby.

Vo vybratých rozhovoroch som sa sústredila na životné príbehy l'udí, ktorí boli počas druhej svetovej vojny prenasledovaní a diskriminovaní ako Ž/židia (120 rozhovorov), ${ }^{4}$ resp. ktorí boli očitými svedkami historických udalostí, atrocít voči ich židovským susedom počas holokaustu ( 80 rozhovorov). Metodológia vedenia rozhovoru bola zameraná na získanie životného príbehu respondenta s hlavným dôrazom na obdobie druhej svetovej vojny, resp. holokaustu. Pritom jedným z tematických okruhov boli aj vztahy respondenta a jeho rodiny s obyvatel'mi lokality, v ktorej žili, a prípadné zmeny týchto vztahovov a kontaktov v dôsledku sociálnych a politických zmien koncom 30. rokov 20. storočia.

Je vôbec možné, aby si pamätníci po desiatkach rokov pamätali, čo zažívali v niekol'komesačnom období trvania druhej ČSR a autonómie Slovenska v nej? Podla mňa otázka takto nestojí. Jedným zo záverov doterajších výskumov je, že tí, ktorých sa zmeny v danom období dotkli osobne a výrazne (identita spomínajúcich pritom zohráva významnú rolu), majú túto historickú dobu zaradenú do osobných spomienok ako samostatný tematický blok. Nie vždy je však súčastou ich spontánne rozprávaného života, ale vyjadrujú sa k nemu až pri doplňujúcich otázkach.

Pri analýze biografických interview ma zaujímalo, aké obrazy respondenti vo svojom rozprávaní vo vzt’ahu k sledovanému obdobiu (od septembra 1938 po marec 1939) konštruujú. Výskumná prax potvrdzuje, že nie je ani tak dôležité to, aké dlhé obdobie uplynulo od doby, ktoré narátori opisujú. Dôležitejšie je, prečo naň spomínajú. Aké silné boli zážitky, ktoré v danom čase prežili, a aké významy mu

4 Vzhl’adom na multiplicitu židovských identít používam písanie pojmu ž/Žid v tejto duálnej podobe. 
spomínajúci prisudzujú v kontexte svojich životných príbehov v súčasnosti. Determinantom vplývajúcim na obsahy týchto spomienok je pochopitel'ne identita (identity) spomínajúcich: ich rod, vek, náboženská, etnická, lokálna príslušnost', ako aj vzdelanie a d’alšie osobné charakteristiky a znaky.

Približne v tretine analyzovaných 200 interview som našla zmienky o situácii na jeseň 1938, resp. narátori reflektujú často dlhšie obdobie až do marca 1939. Vo väčšine prípadov ide o spomienky židovských respondentov. Pracovne ich možno označit’ ako opis zmien v ich každodennom živote v období slovenskej autonómie. Výskumnú vzorku tvoria z hladiska veku ludia, ktorí v sledovanom období boli det'mi, tínedžermi alebo mladými dospelými. Ich vzdelanostná úroveň sa pohybuje od základného po vysokoškolské vzdelanie, v sledovanom historickom období bývali spomínajúci (muži aj ženy) v mestách i na vidieku dnešného Slovenska. Spomienky zachytené v rozhovoroch predstavujú ich osobnú skúsenost' so zmenami, ktoré zasiahli do ich životov v dôsledku udalostí vel'kých dejín.

V akademickom, resp. historiografickom diskurze je sledované obdobie po Mníchove charakterizované dominantným postavením nacistického Nemecka v celom stredoeurópskom priestore a aj na území dnešného Slovenska rýchlym oslabovaním princípov demokracie. Historici na základe analýz archívnych prameňov, procesov v štruktúrach štátnych a správnych inštitúcií na úrovni riadenia štátu, ako aj analýzy prijímanej legislatívy konštatujú: „Základy liberálnej spoločnosti a pluralitnej demokracie: politická tolerancia k opozícii, hladanie konsenzu či diskusia, rovnako ako korektný vztah k menšinám, stále viac absentovali, až sa vytratili z politického života Slovenska. ${ }^{\text {"5 }}$

Spomienky l'udí, ktorí túto dobu zažili, predstavujú konkrétne osobné zážitky a skúsenosti, ako sa prebiehajúce historické udalosti premietli do ich životov. Prerozprávali ich $\mathrm{v}$ podobe, ako si ich s odstupom desiatok rokov (a niekedy aj pod vplyvom dodatočných informácií) vybavujú. Ide o subjektívnu rekonštrukciu ich vlastného životného príbehu v kontexte vel'kých dejín. Udalosti od jesene 1938 prinášali so sebou také zmeny, ktoré zasahovali do zaužívaného spôsobu života obyvatelov Slovenska, ovplyvňovali sociálne vztahy a komunikáciu, na ktorú boli dovtedy zvyknutí. Pamätníci hovoria, čo pre nich samotných znamenalo vytrácanie sa politickej tolerancie a korektnosti či rešpektu k menšinám. Opisujú, akú podobu mali tieto procesy zmeny pre nich a ich blízkych, ako ovplyvnili ich dovtedajší sociálny status v lokalite, vzt’ahy s najbližším okolím, ale aj s reprezentantmi štátnej a cirkevnej moci, resp. ako zasiahli ich privátnu sféru - rodinné vztahy.

Aký charakter majú reflexie sledovaného historického obdobia? Aké situácie, symboly a spomienky sú pre nich znameniami zmeny - kto alebo čo pre nich túto zmenu predstavoval, resp. stelesňoval? Na tieto otázky som hladala odpovede pri obsahovej analýze výpovedí pamätníkov. Reflexie sledovaného obdobia sú rôzne: niektorí stručne, iní všeobecne zmieňujú sa o medzinárodnej situácii v európskom priestore na jeseň 1938, hovoria o vedomostiach, informáciách, ktoré mali o situ-

5 NIŽŇANSKÝ, Eduard. Holokaust na Slovensku. Obdobie autonómie 6. 10. 1938 - 14. 3. 1939. Dokumenty. Bratislava : Nadácia Milana Šimečku, 2001, s. 7. 
ácii v nacistickom Nemecku. Často sú narátori osobní a spomínajú na udalosti, ktoré sa udiali v ich súkromnom a rodinnom živote. V mojej výskumnej vzorke sú zastúpení pamätníci z rôznych oblastí dnešného Slovenska: je medzi nimi jeden respondent z Petržalky, ktorá pripadla po Mníchove nacistickému Nemecku, d'alej obyvatelia území, ktoré sa po prvej Viedenskej arbitráži ocitli v Horthyovskom Mad’arsku, ale zastúpené sú aj skúsenosti obyvatelov z území, ktoré ostali v autonómnej Slovenskej krajine.

Situáciu tesne po Mníchove v Petržalke zachytáva spomienka vtedy 13-ročného mládenca. Október 1938 má v pamäti spojený predovšetkým s dvoma situáciami. Prvá je vizuálnou spomienkou zmeny vo verejnom priestore v súvislosti s núteným odchodom československých vojakov z jeho rodnej obce a z pohraničného československého územia. Armáda musela opustit’ systém vojenských opevnení a nahradili ich vojaci nacistického Nemecka. Zmenu má zachytenú ako obraz výmeny vojakov - reprezentantov štátnej moci. Druhý opis zmeny je osobnejší, hlbšie zažitý. Zostal ako spomienka na t'ažkosti v škole s novým vyučovacím jazykom a na odchod slovenských učitel'ov zo školy: „No, tým dňom, 10. októbrom, vstúpili nemecké vojská do Petržalky, celú ju okupovali, obsadili všetky úrady, ... obsadili kasárne, naše vojsko československé sa stiahlo do Bratislavy, no a tým dňom začal iný život pulzovat' pre občanov Petržalky. Vstúpili do platnosti všetky hitlerovsko-nemecké fašistické zákony a nariadenia [...] Ja som začal ešte začiatkom septembra chodit' do slovenskej mešt'anky, ale dňom okupácie, na druhý deň už to bola nemecká škola. Už naši učitelia... slovenskí učitelia boli evakuovaní, tak ako všetci štátni zamestnanci... A my, čo sme boli obyčajní občania, my sme nemali kam íst', tak sme tu zostali, ... v Petržalke. A pre nás to boli časy vel'mi zlé, t’ažké časy. Celá okupácia... všetky predmety učili v nemčine, ... tak som musel drilovat’ tú nemčinu. Dneska mi je dobrá vec, že viem nemecky, no."6

V sledovanom období sedemročný slovenský chlapec z Dunajskej Stredy, ktorá sa po prvej Viedenskej arbitráži stala mad’arským územím, hovorí z pohladu diet’ata a žiaka o zmene správania v škole i v uliciach mestečka. Jeho spomienka vypovedá o spochybnení jeho vlastných istôt a hodnôt, ktoré pre neho, jeho rodinu, ale aj rovesníkov - spolužiakov dovtedy platili v privátnom (doma) aj vo verejnom priestore (škola). Zneistenie do jeho života vniesli existenčné problémy rodiny, ved' jej slovenský pôvod znamenal zrazu znížený sociálny status. Ďalšou neistotou pre rodinu bolo narukovanie jej živitel'a (otca) do mad’arskej armády. So zmenou sa stretol aj v školskom prostredí. Nositel'mi zmeny, agresívneho správania až šikany voči židovským spolužiakom, boli noví žiaci pochádzajúci z mad’arských území. Tí si so sebou priniesli vlastné normy správania voči Ž/židom, ktoré už platili v Horthyovskom Mad’arsku a mali platit' aj na získaných územiach.

„[...] v 38. nás pripojili k Mad'arsku, no a otcovi napríklad jednoducho neuznali vysokú školu, on... jeho považovali za Felvidéki Tótha..., tak týmto spôsobom. Čiže - bolo to vel'mi zlé. A on narukoval na polroka na vojnu a tam tiež nedostal, ako sa hovorí, tú, to dôstojnícke zaradenie a bol len obyčajným, čo ja viem, desiatnikom. [...] Hned'

6 J. G., nar. 1925 v Petržalke, výskum autorky v roku 2014. 
od začiatku, od začiatku v triede a zvlášt’ tí, ktorí prišli z materských zemí, čo pôvodne boli Mad'ari, tak oni sa chovali úplne povýšenecky a napríklad to boli úplne strašné situácie, ked' neviem, zo šiestej triedy gymnázia prišiel ku nám do druhej triedy a tam jednoducho tie židovské deti začal fackat', alebo tuná [ukazuje na vlasy nad uchom, M. V.] vytrhávat' takto vlasy. Tak to boli úplne pre nás to boli stresové situácie. Nikdy sme také nevideli, nikdy sme o tom nevedeli. My sme sa spolu hrávali a všetko a to, to bolo pre nás skutočne, vel'mi tažké..."

Spomienka 14-ročného židovského mládenca, tiež z Dunajskej Stredy, ešte výraznejšie reflektuje dramatickú zlomovú situáciu a charakter fatálnosti tejto zmeny pre židovských obyvatel'ov v tejto lokalite. Rodné mesto nachádzajúce sa na území, ktoré získalo Mad’arsko, sa stalo priestorom rabovania a násilností, ktoré boli namierené predovšetkým proti židovským obyvatelom. Do mesta boli privezení Ž/židia, ktorí nemali na vtedajšom slovenskom území domovské právo. Takéto nútené st'ahovanie sa dotklo aj príbuzných spomínajúceho. Stali sa nechcenou skupinou na Slovensku, ale aj v Mad’arsku. Zmena správania spoluobčanov $\mathrm{ku}$ jeho otcovi a rodinnému majetku akcelerovaná príchodom reprezentantov mad’arskej štátnej moci predstavovala spochybnenie až negovanie dovtedajších noriem správania a vztahov medzi obyvatel'mi jeho rodného mesta. Predznamenávali zmenu sociálneho statusu jeho rodiny a neisté vyhliadky do budúcnosti, vzhladom na jej židovský pôvod.

„Vtedy došlo v 38. roku už k tomu, že tu sme sa stali Mad'armi, na čo mám vel'mi zlé spomienky... lebo 7. novembra prišli sem Mad'ari a v ten deň v Dunajskej Strede vyrabovali dva židovské obchody. Z toho jeden bol môjho otca a môjho otca chceli obesit'. Takže sme ho museli schovat'.. a ja som videl ako rabujú náš obchod a čo vykrikujú tam l'udia. Takže to bolo pre mňa ako 14-ročného chlapca strašne šokujúce... predošlý deň zo Slovenska už sem došlo niekol'ko autobusov Židov, ktorých zo Slovenska vyložili s tým, že to neni sú Slováci, a to boli Židia, medzi ktorými som mal aj rodinu a tá rodina prišla sem. To bola rodina A., ktorých z Čataja priviezli sem do Dunajskej Stredy tiež, no a tí už boli tu a no a odtial'to zasa Mad'ari tvrdili, že nie sú Mad'ari, tak ich zase vyviezli za hranice. Takže boli medzi dvoma štátmi, medzi Slovenskom a Mad'arskom a už bola zima, a oni tam museli byt'. Takže to bol jeden z vel'kých šokov, druhý šok bol ten deň, ked' prišli mad'arské vojská a že rabovali náš obchod."요

Čím je vek spomínajúcich vyšší, tým zretel'nejšie sú v ich spomienkach zachytené nuansy odlišnosti životných podmienok, vztahov v lokálnom spoločenstve pred a po zmene, ktorú priniesli udalosti jesene 1938. Ich výpovede akcelerujú otázky o vplyve politických rozhodnutí, postupnej zmene politického systému a s tým spojenou legislatívou na každodenný život l'udí. Respondenti hovoria tiež o kvalite informácií, ktoré mali k dispozícii, o ich vplyve na vnímanie a chápanie žitej reality, aj na ich prípadné životné stratégie, plány a rozhodnutia ako sa v zmenenej situácii zachovat'.

7 USC Shoah Foundation Visual History Archive (USC SF VHA), J. T., nar. 1931 v Dunajskej Strede, Interview Code 41297, segm. 8-10.

8 USC SF VHA, F. K., nar. 1924 v Dunajskej Strede, Interview Code: 30039, segm. 39-40. 
V roku 1938 16-ročné dievča pochádzalo z rodiny, v ktorej sa otec aj starší súrodenci zaujímali o politické dianie, v médiách sledovali aj nástup Hitlera k moci. Konštatuje, že mali možnost' získavat' informácie o dianí nielen v bezprostrednom okolí, ale aj v Európe, predovšetkým z rozhlasového vysielania. Zaujímavý je jej opis zážitku z improvizovanej manifestačnej oslavy pričlenenia obce k Mad’arsku. Rovnako aj živá spomienka na protižidovskú výzvu, aby sa agresia obrátila na miestnych židovských obyvatel'ov. Je zrejmé, že zotrvačné mechanizmy pôsobenia sociálnych noriem správania platných „pred zmenou“, ktorými sa riadila sociálna kontrola v lokálnom spoločenstve, ešte zavážili a výzvu stačili spochybnit’ a znegovat'. Jej opis prináša aj náznak reakcií lokálneho spoločenstva na prebiehajúce zmeny a ich vplyv na rodinnú ekonomiku.

„Žial' sme to chápali. Lebo sme vedeli, že čosi sa deje v západnej Európe, ... vedeli sme, čo sa deje. Ved' sme čítali noviny, počúvali rozhlas, aj ked' sme nemali vlastné rádio, ale sme zas mali známych, kde sme mohli počúvat... V dedine našej boli dve rádiá. Dva rozhlasové prijímače, to bol jeden vel'kostatkár a učitel'. Tak učitel' obyčajne vyložil rádio do okna, aby dedina mohla počúvat.' [...] Ked' sa rozhodlo, že pripadne to územie Mad'arsku [dedina respondentky bola na tomto území, M. V.], tak usporiadali chlapi taký pochod po dedine. Len obyčajný taký pochod. A veru, že tam zaznel jeden výkrik »Preč so židmi!« (tedd le a zsidókal!) v mad'arčine a na to sa ozval d'alší hlas, sme počuli: »Čo netreba, to netreba!« Čiže, aby bol s tým ten dotyčný ticho. A nedalo sa pocitovat’ predbežne nič, až na to, že boli určité rodiny, boli $v$ menšine, ktoré profitovali z tých zmien... Tým, že zabrali to územie a tým, že fašizmus sa rozširoval, tak vždy sa nájdu l'udia, ktorých zmýšlanie sa mení. Židia boli odstavení od všetkých profesií... bolo možné použit' tichých spoločníkov a viem, že vtedy naši viedli obchod d'alej spolu so susedom pod jeho menom." ${ }^{\text {"9 }}$

Vtedy 22-ročná mladá žena hodnotí obdobie jesene 1938 a jej dôsledky pre seba a rodinu. Jej spomínanie na úroveň a kvalitu informácií o dianí v bezprostrednej blízkosti i v nacistickom Nemecku je odlišné od predchádzajúcej výpovede. Informácie do jej rodiny prinášali priamo židovskí emigranti z nacistického Nemecka. V spomienke hodnotí vtedajšie postoje a reakcie svojho okolia na správy o udalostiach v nacistickom Nemecku aj na prichádzajúcu zmenu. Upozorňuje na sklon l'udí relativizovat' zlé správy a verit', že sa týkajú vzdialených miest a l'udí. Pre ňu konkrétnu zmenu predstavuje zmenené správanie najbližšieho okolia, a fakt, že ostala oddelená od časti rodiny novou hranicou. Zmena pre ňu znamená obmedzenie slobodného pohybu, ako aj začiatok spoločenskej izolácie židovských obyvatelov v meste Prešov.

„Ja to začnem od 38. roku, ked'sa rozpadlo Československo. V Prešove sme to vel'mi intenzívne prežívali, lebo Košice odpadli. Po prvé som tu ( $v$ KE) mala rodinu a hlavne sestru a synovca, ktorého sme tak zbožňovali. A sme vedeli, že už tak lahko sa ku nim a ani oni ku nám nedostanú. A prichádzali evakuanti z Košíc, z Podkarpatskej Rusi, to strašne pôsobilo na človeka. Vôbec ten 38. rok, Anschluss s Rakúskom, mobilizácia, potom v jeseni zase mobilizácia a Mníchov, hej? To všetko vel'mi pôsobilo na

9 USC SF VHA, P. R., nar. 1922 vo Vel'kých Kapušanoch, Interview Code: 17733, segm. 22, 26-27. 
nás. Ešte stále sme netušili, čo nasleduje, lebo človek je už taký, že kým ma to netlačí, tak ešte nemyslím, že sa to môže zvrhnút'... Len prichádzali... vtedy nebola televízia, ani rádio, tak málo, na málo miestach boli rádiá, že sme nevedeli čo všetko sa odohrávalo v Nemecku, v Rakúsku všade, hej? Ale už pomaly to na nás doliehalo... No a teraz prišiel marec $v$ 39. roku a náhle sa zmenilo vel'mi. L'udia, s ktorými sme boli zadobre, nejak sa už odt'ahovali od človeka, že to už nie je ono, to čo bolo niekedy. Už každý začal mysliet' na tie zadné dvierka, každý myslel na to, že aj u nás to tak môže dopadnút', hej, ako inde. Prichádzali emigranti, aj manžel rozprával, že do Prahy prichádzali z Nemecka ludia. Tam, kde on bol ubytovaný, tak aj tam do tej rodiny prišli emigranti. ${ }^{\text {"10 }}$

Mladá, čerstvo vydatá žena, sa prestahovola v roku 1937 k manželovej rodine do Královského Chlmca. Jeseň 1938 má v spomienkach spojenú s odlúčením od manžela - najprv v dôsledku mobilizácie musel narukovat’ do československej armády, neskôr ako židovský muž žijúci na územiach pripadnutých Mad’arsku mal pracovnú povinnost’ a musel nastúpit' do pracovného tábora. Jeho manželka ostala sama - bez možnosti kontaktu s ním, svojimi rodičmi a d’alšími pokrvnými príbuznými, ktorí zostali po zmene hraníc na Slovensku. Zmena jej priniesla odlúčenie a osamelost' v novom prostredí.

V roku 1937 sa ako 21-ročná vydala: „[...] Ale dlho netrvalo naše manželstvo, lebo on stále chodil na vojenské manévre, aj mobilizácia bola. Až potom, ked' sme sa stali, ked' nás pripojili k Mad'arsku roku tisícdevät'sto [odmlka, premýšla] tridsat.... devät ${ }^{11}$, tak odišiel do pracovného tábora. Išiel do Košíc, tam ich sústredili všeckých. Raz som ho mohla navštívit'. Tak som ho aj navštívila a od tej doby som ho už nevidela [...] bola som odlúčená od mojich najbližších všeckých. Oni žili na Slovensku a ja na Mad'arsku..." ${ }^{\text {"2 }}$

Pre d’alšie pätnást'ročné dievča znamenali vtedajšie udalosti v jeseni 1938 tiež zhoršenie životných podmienok. Neistota a strach sú emócie, ktoré charakterizujú jej spomienky na tieto zmeny. Spomína na znemožnenie práce otcovi - živitelovi rodiny aj na vysídlenie celej rodiny. Tieto udalosti otriasli jej dovtedajšími predstavami o svete. Vynútený odchod z jej rodnej obce v sprievode predstavitela novej štátnej moci a poníženie otca, autority rodiny - to sú momenty, ktoré má spojené s týmto obdobím.

„[...] Mad’ari nás strašne šikanovali... Pravdaže sme vedeli, že hrozba ide z Nemecka... lebo noviny sme čítali... Dost'sme boli v strachu, a hlavne hovorím, tá mad'arská éra nám vel'mi ublížila. Zobrali nám živnost', vyhostili z Myslavy... Tá čast', z ktorej pochádzal otecko, nebola zabratá Mad'armi, tak sme na vlastnom voze odchádzali, ale mad'arský četník otcovi nedovolil sediet' na voze, musel íst' za ním." ${ }^{.13}$

10 USC SF VHA, G. U., nar. 1916, Interview Code 18589, segm. 31-33.

11 Respondentka si pričlenenie južných častí Slovenska Mad’arsku v spomienke o rok posunula.

12 USC SF VHA, Ž. G., nar.1916, Poša, Interview Code: 14874, segm. 6-7.

13 USC SF VHA, A. R., nar. 1923 Myslava, Interview. Code: 20159, segm. 13-14. 
Mladý muž z Ružomberka pracoval na jeseň 1938 v rodinnom obchode. Dovtedajší status obchodníckej rodiny v lokálnom spoločenstve bol spochybnený. Jeho spomienky na zmenu sú spojené so šikanou zo strany členov Hlinkovej gardy aj s narastajúcim antisemitizmom v meste. ${ }^{14}$

„Tak to už bolo horšie, lebo za autonómie, vtedy už začal ten antisemitizmus byt' citel'ný... Ako príklad uvádzam za druhej republiky, ked' bola založená [Hlinkova, M. V.] garda. Tak prvá vec bola, že robili u nás domovú prehliadku pod tou zámienkou, že hl'adali mad'arské zástavy. Tak to už bol taký antisemitický krok, bola to len zámienka. Vtedy už ten antisemitizmus začal... No a potom samozrejme za slovenského štátu to pokračovalo."15

Spomienka v danom období šest'ročného chlapca z Humenného prináša osobnú skúsenost' s tým, čo dnes historici nazývajú prvé deportácie ${ }^{16}$ židovských obyvatel'ov z územia Slovenska. Diali sa tesne po verdikte prvej Viedenskej arbitráže v dôsledku nariadenia vtedajšieho predsedu vlády Jozefa Tisa. ${ }^{17}$ To, samozrejme, vtedy chlapec nevedel. Ostala mu spomienka na bývanie s celou rodinou v stohu slamy a neskorší návrat domov. Prázdny vyplienený byt, ale aj nezištná pomoc cudzej ženy, to sú pre neho momenty charakterizujúce zmenu.

„Na jeseň 1938 všetkých tých židov, ktorí pochádzali z Mad’arska alebo z Pol'ska, ktorí nemali občianstvo, domovské právo, tak ich stáahovali preč. My sme boli hned' v prvej várke a vyst'ahovali nás na hranicu mad’arskú. Viete, ja som mal vtedy šest' rokov, som mal íst' do prvej triedy, takže moja pamät' na tú dobu je útržkovitá... pamätám sa, že môj starší brat mal perinu či dve a bývali sme v stohu slamy. Tam sme boli asi desat' lebo štrnást' dní na tej hraničnej čiare v podstate. Bolo tam vel'mi vel'a rodín, desiatky a desiatky. Potom došlo k tej politickej dohode a my sme sa vrátili domov. Prišli sme do toho nášho domčeku a tam nebolo nič. Proste ani lyžička. Všetko si susedia rozobrali. Tak tá pani F., ona bola vdova a mala $v$ takom dlhom nájomnom dvore byt, $v$ prvom murovanom dome býval majitel' a za tým išli budovy $z$ válkov [stavebný materiál z nepálenej hliny, M. V.], tá nás pritúlila, mala tri izby tak za sebou. U nej sme bývali až do roku 1942, až do transportov. V tom období som chodil do prvej triedy ešte do štátnej školy, pamätám sa, ako nás učili o tatíčkovi Masarykovi, $v$ tridsiatom deviatom sme tiež ešte chodili do štátnej školy, ale prelepovali nám strany $v$ čítanke [po 14. marci 1939, M. V.] a v štyridsiatom roku nás zo školy povyhadzovali. ${ }^{\prime 18}$

Rovnako starému chlapcovi - prváčikovi v Trenčíne sa zmena na jeseň 1938 spája s nepríjemným zážitkom s dovtedajším kamarátom priamo v triede. Predstavuje

14 Jeho spomienka korešponduje a dopíňa konkrétnou situáciou poznatky, ktoré priniesol historiografický výskum. Pozri NIŽŇANSKÝ 2001, s. 29-32.

15 USC SF VHA, A. R., nar. 1911 v Ružomberku, Interview Code: 27473, bez segmentov, fragment od 17. minúty 57. sekundy po 19. minútu.

16 Túto udalost' je možné v kontexte súčasných poznatkov o tzv. riešení židovskej otázky na Slovensku vnímat' ako predzvest' charakteru celého procesu, ktorý vrcholil masovými deportáciami v roku 1942.

17 NIŽŇANSKÝ 2001, s. 9-10.

18 Z. B., muž, nar. 1932 v Humennom, rozhovor nakrútený v auguste 2006 v rámci výskumu osudov detí počas holokaustu. Bol spracovaný v monografii VRZGULOVÁ, Monika. Deti holokaustu. Bratislava : Dokumentačné stredisko holokaustu, 2007, s. 53-62. 
jeho prvú konfrontáciu s faktom, že inakost' (fakt, že pochádza zo židovsko-slovenskej rodiny) vyvoláva aj nové negatívne reakcie najbližšieho okolia.

„V podstate som pochopil, že proste mat'židovské príbuzenstvo, to nie je len mat' radost'a pocit, že si obklopený láskou, ale že je to aj nepríjemné alebo nebezpečné. Mal som takého, nedá sa to nazvat' kamarát, lebo sme boli malé deti, ale odkedy sa pamätám, sme sa hrávali v piesku a v parku a sme boli vždy spolu a tak. Takže naši rodičia ešte prosili učitel'a $v$ prvej triede, aby nás posadil spolu. No a tento chlapec... no Pal'ko sa volal, krstné meno iba poviem, tento Pal'ko proste vstal ešte pred začiatkom vyučovania a povedal, že poprosil teda učitel'a, aby ma odsadil. Aby ho odsadil odo mňa. Že on už nechce so mnou sediet'. No a učitel' sa pýta: „A prečo?« Bol úplne ako vydesený, pretože... No, že preto, že Kornel smrdí. A on mu hovorí: »no ako - že smrdí ?" »No, otec mi povedal, že židia smrdia a Kornel je žid."Takže si odsadol a nechal ma samého. Teda som sedel v tej lavici a nevedel som pochopit', že čo sa deje. Jednak som vedel, že to nie je pravda, že nikto z mojej rodiny nesmrdel, že naopak boli šialene čistotní, až nepríjemne čistotní, lebo ma nútili umývat' viac, ako som mal sám chut', a na druhej strane to, že ten kamarát, že toto sa stalo, to bola šialená skúsenost' pre mňa. ${ }^{.19}$

Spomienka vtedajšej študentky gymnázia v Trenčíne jasne umiestňuje začiatok protižidovských nálad a postojov v meste už do jesene 1938. Prvé vydelovanie z kolektívu rovesníkov, osudy českých učitel'ov a ich násilné odchody - to sú obrazy, ktoré má s týmto obdobím spojené v pamäti. Predstavujú začiatok zmeny, ktorá jej po čase priniesla ešte výraznejšie prejavy diskriminácie.

„Každý spomínal začiatok holokaustu štrnásteho marca tridsat'devät', ale ja z vlastnej skúsenosti viem, že fakticky sa to začalo už pri mobilizácii, v tridsiatom ôsmom roku. Ked' sme chodili do školy, vtedy už sa začali zoskupovat' určité spolužiačky do Hlinkovej mládeže a začali od nás bočit'. Už bolo vidiet' ten rozdiel, jako bolo do tej doby a ako sa chovali potom. Taktiež mnohí už z českých profesorov, ktorých bolo u nás na gymnáziu prevažne, sa začali zaoberat's tým, že zo Slovenska odídu. Ja mám, ja spomínam na jeden zážitok, ktorý bol cez mobilizáciu a to bolo na židovský Nový rok, ked' bola vlastne tá mobilizácia vyhlásená, že celá mládež vyšla hore v kostole na chór a spievala sa hymna Kde domov můj. Mnohí z tej staršej generácie nám toto velice zazlievali. Tí rozumní s nami súhlasili, lebo ich názor bol, že ked' by Hitler prepadol túto čast' Československa, že by bolo so všetkými židmi koniec. V tridsiatom deviatom, štrnásteho marca to už skutočne bolo na škole velice pre nás t’ažko... Ale môžem povedat', že naša triedna profesorka, pani profesorka M. prišla za nami a hovorila: "Dievčence, držte sa, musíte to vydržat', raz bude aj ináč." To jej teda nikdy sme nezabudli... Potom nastala výmena profesorov, pretože všetci do konca školského roku, všetci českí profesori odišli od nás. My sme ešte jeden rok v tej škole vydržali, no ale potom už bol numerus nullus a museli sme všetky školu opustit.',20

19 USC SF VHA, K. F., nar. 1932 v Trenčíne, Interview Code:16541, segm. 43-44.

20 Videoarchív Nadácia M. Šimečku, Bratislava, E. F., žena, nar. 1927, interview 92. 
Maturantka v školskom roku 1938 - 1939 zaznamenala zmenu priamo v škole. V tomto jej poslednom školskom roku sa stretli dve kvalitatívne odlišné obdobia. Na začiatku ešte bezstarostné kontakty a vztaha mládeže rôzneho pôvodu. Podla jej slov pokroková (,skôr neologická") židovská komunita žila v lokálnom spoločenstve v duchu náboženskej tolerancie. Tu je tiež dôležité si uvedomit', že vtedy mladé dievča spomína na svoju vekovú skupinu a jej vztahy, nie na dospelých aktérov lokálneho spoločenstva. Jej skúsenost' je dokladom toho, že napriek vnucovaniu zmeny správania k židovským spolužiakom zo strany autorít školy, zafungovali ešte $\mathrm{v}$ danom období vzory správania tolerancie a úcty, ktoré mali mladí l'udia osvojené socializáciou v predchádzajúcom období Československej republiky.

„V Ružomberku bola židovská komunita vel'mi zaujímavá, pokroková... skôr neologická a tak, priatel'stvo s inými náboženstvami, to bolo úplne prirodzené, mali sme kamarátov, dievčatá chodili s krestáanskými chlapcami, krestanskí chlapci dvorili židovským dievčatám, boli tam miešané manželstvá a myslím, že vzt'ah bol úplne prirodzený, tak ako medzi mladými l'ud'mi mal byt'. No, l'udovú školu som vychodila $v$ Ružomberku, potom som navštevovala gymnázium reálne a v búrlivých rokoch tridsatosem, tridsat'devät' som maturovala. Tak zažila som pálenie kníh českých, pokrokových a zažila som aj štrnásty marec priamo, v centre diania v Ružomberku. $V$ tridsiatom deviatom v máji som maturovala, tak ako všade sa žiaci lúčili s tablom, každá trieda maturitná mala svoje tablo. My sme mali na table Andreja Hlinku a mali sme profesora, ktorý bol Nemec, taký B. sa volal a presviedčal našich spolužiakov... aby nedali týchto židovských spolužiakov na to tablo a naši spolužiaci vtedy už sa ohradili proti tomu, že toto nebude žiadne tablo a nakoniec sme na tom table boli. ${ }^{\text {،21 }}$

V nasledujúcej spomienke bratislavský stredoškolák ilustruje vztahy žiakov k českým učitel'om a ich konkrétny skutok pri nútenom odchode triednej učitel'ky na jeseň 1938. Tento osobný zážitok podporuje obraz českých učitelov v spomienkach d’alších pamätníkov. Vystupujú v nich v danom období ako významné formatívne vzory pre mladú generáciu na Slovensku.

„My sme mali väčšinou českých profesorov, ktorí nás na obchodnej akadémii učili. Tá škola proste, tých českých profesorov, ked' došiel Slovenský štát, vyhnali do Čiech. A naša triedna bola Češka. A ked' išla, išla náhodou okolo školy, tak celá trieda vybehla k oknám a začala skandovat' Dovidenia. Na druhý deň už prišli všelijakí eštebáci, slovenskí gardisti a začali vyšetrovat', že čo to znamenalo dovidenia a kto začal. Nenašli vinníka. Bolo (to) spontánne. Takže my sme týchto českých učitelov mali skutočne radi. Lebo to boli múdri l'udia. A tí nás aj vel'a naučili. ${ }^{22}$

\section{Záver}

Súčasné vedecké poznatky o nedávnej minulosti tvoria výsledky výskumov rôznych vedných disciplín. Platí to aj o období od jesene 1938 do jari 1939. Charakterizovala ho zásadná a pomerne rýchla sociálna zmena zasahujúca aj obyvatelov

21 Videoarchív Nadácia M. Šimečku, Bratislava, M. N., žena, nar. 1922, interview 23.

22 Videoarchív Nadácia M. Šimečku, Bratislava, J. K., muž, interview 12. 
dnešného Slovenska. Historici hovoria o kombinácii viacerých faktorov, ktoré ju akcelerovali a živili: konflikty o zdroje a hodnoty, resp. aj územné nároky na medzinárodnej úrovni, zmena politického režimu a ideológie na vnútroštátnej úrovni. Parlamentnú demokraciu v Československu vystriedali procesy vedúce $\mathrm{k}$ autoritárskemu politickému systému. Politicky a legislatívne garantovaná rovnost' všetkých obyvatelov krajiny pred zákonom sa rýchlo stávala minulostou. Etnologický kvalitatívny výskum zameraný na výskum pamäti prináša poznatky o tom, akým spôsobom si na tieto zmeny spomínajú pamätníci, aké udalosti, situácie, zážitky pre nich túto zmenu predstavujú.

Cielom mojej štúdie bolo na vybratých fragmentoch spomienok získaných metódou oral history sledovat' obrazy sociálnej zmeny od jesene $1938 \mathrm{v}$ individuálnych spomienkach. Analyzovala som 200 interview (z nich bolo 120 židovských). Len $\mathrm{v}$ tretine rozhovorov (prevažne so židovskými respondentmi) som našla krátke pasáže, v ktorých respondenti spomínali na príbehy či situácie spojené so sledovaným historickým obdobím. Ich spomienky sú ovplyvnené mnohými faktormi: vekom spomínajúcich, ich pôvodom, rodom, vzdelaním, aj tým, na akom území v čase zmeny žili, ako dokážu chápat’ súvislosti, procesy okolo seba a v neposlednom rade aj ich schopnost'ou rozpamätat' sa. Ako som už uviedla, v mojej vzorke v sledovanom období prevažuje skúsenost' židovských respondentov. Predovšetkým ich spomienky obsahujú konkrétne momenty, ktoré sa ich osobne dotýkali a v danom období pre nich predstavovali symbol nastávajúcej zmeny. Samozrejme, nejde o reprezentatívne výskumy, a tak je táto proporcia len ilustratívna, aj ked' logická a výpovedná. Nárast antisemitizmu v sledovanom období v celej Európe a jeho prejavy aj vo vtedajšej spoločnosti Slovenska zasahovali všetky úrovne a oblasti života. Fatálne ovplyvnili život židovskej komunity, ${ }^{23}$ preto sa spomienky na toto obdobie objavujú predovšetkým v naratívoch jej členov.

Analyzované biografické naratívy predstavujú minoritnú optiku a skúsenost' - ide o l'udí so židovským pôvodom, slovenských obyvatelov, ktorí sa stali po zmene hraníc minoritou v novom štáte, ale aj o Slovákov vo „vlastnom štáte“, no nesúhlasiacich s nastupujúcim režimom a jeho ideológiou. Sociálna zmena im od jesene 1938 zasiahla radikálne (a negatívne) do životov, a tak o nej vo svojich životných príbehoch hovoria.

Hoci má sociálna zmena v analyzovaných spomienkach celú škálu podôb, je možné nájst' spoločné znaky. Zmeny, ktoré opisujú cez dnešnú optiku, rozkolísali a narušili dovtedy platné sociálne normy a vzorce správania na lokálnej úrovni. Spomínajúci zdôrazňovali neistotu, nový negatívne vnímaný sociálny status a z neho vyplývajúce životné možnosti. Sociálne normy a hodnoty, zaužívané spôsoby sociálnej komunikácie, ktoré spoluvytvárali ich dovtedajší každodenný svet,

23 Viac: SALNER, Peter. Židia v období autonómie Slovenska. In POJAR, Miloš - SOUKUPOVÁ, Blanka ZAHRADNÍKOVÁ, Marie (eds.) Židovská menšina za druhé republiky. Praha : Židovské muzeum 2007, s. 132-145; SALNER, Peter. Židovská komunita na Slovensku medzi demokraciou a holokaustom. In POJAR, Miloš - SOUKUPOVÁ, Blanka - ZAHRADNíKOVÁ, Marie (eds.) Židovská menšina v Československu ve třicátých letech. Praha : Židovské muzeum v Praze, 2004, s. 83-95. 
boli nahrádzané novými, ktoré re-kategorizovali obyvatel'ov a fatálnym spôsobom zasahovali do ich životov.

Spomienky pamätníkov sa viažu na isté body zvratu. Reprezentujú skúsenosti z rôznych oblastí dnešného Slovenska. Narátori z území zasiahnutých verdiktom prvej Viedenskej arbitráže a jej dôsledkami opisujú zmenu spôsobenú posunutím štátnej hranice: príslušnost' do iného štátu, s inými platnými zákonmi a s odlišnými zaužívanými normami správania k menšinám (predovšetkým k židovskej). Ďalší reflektujú pokus autonómnej slovenskej vlády o prvé deportácie nežiaducich židovských obyvatelov bez domovského práva z územia „okliešteného Slovenska“ po prvej Viedenskej arbitráži či akceleráciu otvoreného (spočiatku) psychického a verbálneho teroru zo strany napríklad členov Hlinkovej gardy voči židovským a českým spoluobčanom, ale aj voči Slovákom previazaným s predchádzajúcim československým obdobím. Ďalší respondenti uvádzajú zážitky spojené s kvalitatívnymi zmenami v politickom systéme vtedajšej spoločnosti Slovenska, s ohrozením demokratických princípov rozpadajúceho sa československého štátu a nástupom nových autokratických politických elít, ako aj so zmenami noriem správania a sociálnych vztáahov na mikroúrovni spoločnosti.

Významné pre udržiavanie pamäti - individuálnej, skupinovej/sociálnej či kultúrnej sú emócie. Tie bývajú akcelerátorom spomínania, ktoré je úzko prepojené s procesmi sebaidentifikácie. Ako hovorí Aleida Assmann: „Spomínat'sa bude na to, čo sa pokladá za nápadné, čo urobilo hlboký dojem. Emócie sú posilňovače pozornosti, a prispievajú tiež ku stabilite spomienok. Spája ich tiež to, že vybraté spomienky posilňujú skupinovú identitu a skupinová identita posilňuje spomienky; inými slovami: vztáa medzi spomienkami a identitou je uzavretý do kruhu. ${ }^{24}$

Spomienky na jeseň 1938, ako je evidentné aj z vybratých fragmentov biografických naratívov, sú spojené skôr s negatívnymi emóciami - obavami, pocitmi neistoty, úzkosti, strachu, opustenosti či sklamania. Spomínajúci v procese rozprávania rekonštruujú aj svoju (vtedajšiu) identitu, svoju príslušnost' ku skupine obyvatelov, pre ktorú daná zmena znamenala ohrozenie, stratu dovtedajšieho sociálneho statusu aj životných istôt. Predovšetkým išlo o (niekedy až vnútenú) príslušnost' k židovskej komunite, ale aj k iným skupinám obyvatelov, ktorí sa touto zmenou ocitli v novej, zhoršenej situácii.

Fragmenty zo spomienok pamätníkov predstavujú nielen ich individuálnu pamät'. Tá sa komunikáciou, zdiel'aním $\mathrm{v}$ rámci rodiny, vekovej či inej sociálnej skupiny stáva komunikatívnou pamätou. ${ }^{25}$ Tento typ pamäti má podla A. Assmann ohraničenú životnost' $80-100$ rokov (resp. trvanie počas troch až piatich generácií). Pokým pre komunikatívnu pamät' je kl'účové prepojenie na individuálneho nositela spomienky,

$24 \mathrm{~V}$ origináli: „Erinnert wird, was als auffällig wahrgenommen wurde, was einen tiefen Eindruck gemacht hat, was als bedeutsam erfahren wurde. Emotionen sind die Aufmerksamkeitsverstärker, die auch zur Stabilisierung der Erinnerung beitragen. Gemeinsam ist ihnen ebenfalls, daß die Erinnerungen, die ausgewählt werden, die Identität der Gruppe stärken, und die Identität der Gruppe die Erinnerungen befestigt; mit anderen Worten: das Verhältnis zwischen Erinnerungen und Identität ist zirkular." ASSMANN, Aleida. Soziales und kollektives Gedächtnis, 2006. Dostupné na internete: http://www.bpb.de/veranstaltungen/dokumentation/128665/panel-2-kollektivesund-soziales-gedaechtnis.

25 A. Assmann hovorí, že komunikatívna pamät' sa kreuje v prostredí, ktoré charakterizuje územná blízkost', pravidelné interakcie, kolektívne formy spolunažívania a zdielanie skúsenosti. ASSMANN 2016, s. 13-14. 
kultúrna ${ }^{26}$ pamät' už pracuje so skúsenostami a vedomostami, ktoré sú oddelené od ich individuálnych nositel'ov a sú prenášané materiálnymi nositel'mi - médiami a inštitúciami. Spomienky zachytené v biografických naratívoch pamätníkov predstavujú teda súčast' komunikatívnej pamäti, ktorej vybraté prvky môžu za istých okolností spoluvytvárat' kultúrnu pamät', resp. spolupodielat' sa na konštruovaní verejného diskurzu o danom historickom období. Spomienky predstavujú sociálne, kultúrne a politické konštrukty, ktoré sa menia v čase a ktoré majú svoj vlastný historický vývoj, pripomína Aleida Assmann. Pamät' môže byt' výsledkom zámernej a riadenej politiky pamäti a formovaná zhora, ale môže vznikat' aj zdola ako pamät' generácí́. Kultúrna a v jej rámci politická a národná pamät' je ukotvená v politických inštitúciách, podporovaná národnými (štátnymi) symbolmi, vyvolávaná pripomínaním udalostí a ovplyvňuje spoločnost' zhora. V tejto súvislosti môžeme hovorit' o politike pamäti (a zabúdania), ktorá zdôrazňuje úlohy politiky vo vytváraní kolektívnej pamäti inštrumentalizáciou a vyzdvihovaním konkrétnym historických udalostí a osobností, na druhej strane zanedbávaním, potláčaním iných, čo vedie ku kolektívnej amnézii. ${ }^{27}$

Spomienky židovských aj nežidovských pamätníkov na rok 1938 zachytené s viac ako polstoročným odstupom predstavujú skupinovú skúsenost', komunikatívnu pamät špecifickej skupiny obyvatel’ov v generácii dnešných (pra)starých rodičov. Ako je zrejmé aj z obsahov, ktoré sú komunikované vo verejnom diskurze, tieto spomienky sa len vel'mi pomaly, ak vôbec, stávajú súčastou dnešnej kultúrnej a politickej pamäti. Tento krátky historický úsek je prekrytý emočne silnejšími, vypätými spomienkami na obdobie holokaustu, resp. na obdobie Slovenského národného povstania či záverečných bojov druhej svetovej vojny, ktorých predohrou boli udalosti posledných mesiacov roka 1938.

26 Tamže, s. 18-21.

27 Tamže, s. 21-22.

Cituj:

VRZGULOVÁ, Monika. Sociálna zmena v biografických naratívoch obyvatel’ov dnešného Slovenska. Od Mníchova po 14. marec 1939. In Forum Historiae, 2019, roč. 13, č. 1, s. 131-143. ISSN 1337-6861. DOI: https://doi.org/10.31577/forhist.2019.13.1.9

$\cdots$

PhDr. Monika Vrzgulová, CSc.

Ústav etnológie a sociálnej antropológie SAV

Klemensova 19

81364 Bratislava

Slovenská republika

monika.vrzgulova@savba.sk 